\title{
Effects of colostrum and milk replacer feeding rates on intake, growth, and digestibility in calves
}

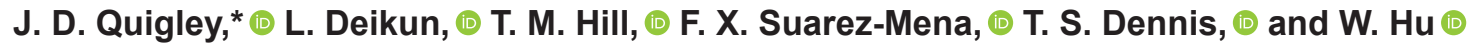 \\ Nurture Research Center, Provimi, Cargill Animal Nutrition, Brookville, $\mathrm{OH} 45309$
}

\section{ABSTRACT}

Newborn Holstein male calves $(\mathrm{n}=50)$ born on a single dairy farm were assigned randomly at birth to receive 3 feedings of $1.8 \mathrm{~L}$ of pooled maternal colostrum (MC) at 1, 6, and $12 \mathrm{~h}$ of age or 1 feeding of $500 \mathrm{~g}$ of a colostrum replacer reconstituted to $1.8 \mathrm{~L}$ at $1 \mathrm{~h}$ of age, followed by 2 feedings of $227 \mathrm{~g}$ of a commercial milk replacer (MR) reconstituted to $1.8 \mathrm{~L}$ at 6 and $12 \mathrm{~h}$ of age $(\mathrm{CR})$. All feedings were administered by esophageal feeder. At 2 to $3 \mathrm{~d}$ of age, calves were transported to the experimental facility and assigned within colostrum group to receive $0.66 \mathrm{~kg} / \mathrm{d}$ dry matter $(\mathrm{DM})$ of $\mathrm{MR}$ to $39 \mathrm{~d}$, and then $0.33 \mathrm{~kg} / \mathrm{d}$ to $42 \mathrm{~d}(\mathrm{MRM})$ or $0.77 \mathrm{~kg} / \mathrm{d}$ of MR DM to d 13, $1.03 \mathrm{~kg} / \mathrm{d}$ for $22 \mathrm{~d}$, and $0.51 \mathrm{~kg} / \mathrm{d}$ for $7 \mathrm{~d}$ (MRH). The MR contained $25.8 \%$ crude protein and $17.6 \%$ crude fat (DM basis) and was based on whey proteins and lard as the primary fat source. Calf starter $(21.7 \%$ crude protein, $15.7 \%$ neutral detergent fiber, $37.4 \%$ starch, DM basis) and water were available for ad libitum consumption throughout the 56-d study. Serum IgG and total protein were measured at 2 to $3 \mathrm{~d}$ of age. Intakes of MR and calf starter were monitored daily. Calf health and fecal scores were also monitored daily. Body weight was measured weekly, and hip width and body condition score were monitored every 2 wk. Digestion of DM, organic matter, crude protein, and ether extract were determined at 1 and 3 wk from 5 calves randomly selected within treatment and using chromic oxide as a digestibility marker added to the MR. Calves fed CR had lower serum IgG and total protein than calves fed MC. Also, calves fed CR grew more slowly, consumed less calf starter, and were less efficient to $56 \mathrm{~d}$ than calves fed MC. The number of days calves were treated with veterinary medications was higher when calves were fed CR. Calves fed MC$\mathrm{MRH}$ gained more BW than other calves from 3 to 8 wk of age. Calves fed CR-MRH consumed less calf

Received March 25, 2019.

Accepted August 16, 2019.

*Corresponding author: jquigley@provimi-na.com starter than other calves during wk 7 and 8. Digestion of nutrients at 1 and 3 wk of the study was unaffected by type of colostrum or level of MR fed and did not change from 1 to 3 wk. Over the first 2 mo of life, the calves fed MRH consumed less calf starter than calves fed MRM, but average daily gain or hip width change did not differ. One feeding of CR followed by 2 feedings of MR in the first $24 \mathrm{~h}$ likely reduced absorption of IgG from CR and contributed to differences in health and growth. Differences in animal performance observed in this study were unrelated to MR digestibility.

Key words: feeding rate, colostrum, milk replacer, animal performance

\section{INTRODUCTION}

Feeding maternal colostrum has been shown to increase absorption of nutrients such as glucose (Steinhoff-Wagner et al., 2011, 2014; Hammon et al., 2012) and improve intestinal morphology and absorption of nutrients compared with formula (Blättler et al., 2001; Roffler et al., 2003). Yang et al. (2015) reported that first-milking colostrum supported greater BW gain in the first week of life and improved intestinal morphology compared with transition milk (from 2-3 d after calving) or milk from the farm bulk tank.

Colostrum replacement products contain IgG derived from colostrum or blood plasma, as well as biologically active compounds depending on the ingredients used and methods of processing. Some research suggests that the growth, efficiency, or health of calves may be reduced when calves are fed colostrum replacers (Jones et al., 2004; Swan et al., 2007; Priestley et al., 2013; Lago et al., 2018) although other data report no differences (Mee et al., 1996; Quigley et al., 2001, 2017). The increased proliferation of intestinal tissue following colostrum ingestion could influence the digestibility of nutrients in neonatal calves. Several researchers (Radostits and Bell, 1968; Arieli et al., 1995; Guilloteau et al., 2009) suggest that the digestibility of milk or milk replacer (MR) increases in the first 2 to $3 \mathrm{wk}$ after birth, but others (Liang et al., 2016) report that 1-wkold calves competently digest MR. Improved intestinal 
function from consumption of colostrum could affect the digestion of nutrients and animal performance. Our objective was to determine intake, growth, and digestibility in young calves on different colostrum feeding programs in the first $24 \mathrm{~h}$ of life.

\section{MATERIALS AND METHODS}

Newborn Holstein bull calves $(\mathrm{n}=50)$ calves were assigned randomly at birth to receive either $1.8 \mathrm{~L}$ of pooled maternal colostrum at 1,6 , and $12 \mathrm{~h}$ of age (MC) or 1 feeding $(1.8 \mathrm{~L})$ of a colostrum-based colostrum replacer at $1 \mathrm{~h}$ of age followed by $1.8 \mathrm{~L}$ of reconstituted MR (21\% CP, $21 \%$ crude fat, DM basis) at 6 and $12 \mathrm{~h}$ of age (CR). Colostrum was collected from cows shortly after calving by farm workers into a bulk tank. The time after calving when MC was collected was not controlled. Aliquots of approximately $10 \mathrm{~L}$ were delivered to the maternity area 3 times per day. Thus, the MC used was pooled from multiple cows and was not from the dam. Approximately 25 $\mathrm{mL}$ of $\mathrm{MC}$ and reconstituted $\mathrm{CR}$ were collected before each feeding and frozen before analysis for IgG by radial immunodiffusion (Triple J Farms, Bellevue, WA). Thawed samples were diluted 4:1 with distilled water before analysis. A subsample was also sent to Eastern Laboratory Services (Medina, $\mathrm{OH}$ ) for analysis of protein, fat, and lactose (Fourier transform infrared analysis, MilkoScan 7; Foss, Hillerød, Denmark) as validated by Løkke et al. (2016). Osmolality was estimated from freezing point depression (AOAC International, 2000; method 980.15, 33.2.33).

The colostrum replacer product was derived from spray-dried bovine colostrum and contained 30\% IgG. The product $(500 \mathrm{~g})$ was reconstituted to $1.8 \mathrm{~L}$ and fed within the first hour after birth. Thereafter, $227 \mathrm{~g}$ of a commercial MR (21\% CP, $21 \%$ fat, DM basis) was reconstituted to $1.8 \mathrm{~L}$ and fed at 6 and $12 \mathrm{~h}$ of age. All feedings in the first $24 \mathrm{~h}$ were administered by esophageal feeder. We estimated the apparent efficiency of IgG absorption (AEA) assuming that plasma volume was $8.9 \%$ of birth BW (Quigley et al., 1998). On d 2 and 3 , calves were fed pasteurized waste milk $(1.8 \mathrm{~L}$ fed twice daily) until they were transported by truck approximately $3.5 \mathrm{~h}$ to the experimental facility.

Upon arrival at the facility, calves were unloaded and placed in individual pens to begin the 56-d study. Calves were weighed and measured, and a jugular blood sample was collected. Hematocrit was determined using a microhematocrit centrifuge, and the remaining sample was centrifuged $(3,000 \times g$ at room temperature for $20 \mathrm{~min}$ ) to separate serum. A sample of serum was evaluated using an optical Brix refractometer (Sper Scientific, Scottsdale, AZ) to measure Brix concentration.
Total serum protein concentration was also estimated using an optical refractometer (Atago USA Inc., Bellevue, WA). The remaining serum was stored at $-20^{\circ} \mathrm{C}$ until analyzed for IgG by radial immunodiffusion as for colostrum, but without sample dilution.

Within colostrum programs, calves were assigned randomly to receive daily (1) $0.66 \mathrm{~kg}$ of $\mathrm{MR}$ (DM) fed for $39 \mathrm{~d}$, and then $0.33 \mathrm{~kg}$ of MR DM for $3 \mathrm{~d}$ (milk replacer moderate; MRM); or (2) $0.77 \mathrm{~kg} / \mathrm{d}$ of MR (DM) for $13 \mathrm{~d}, 1.03 \mathrm{~kg} / \mathrm{d}$ MR (DM) for $22 \mathrm{~d}$, and $0.51 \mathrm{~kg} / \mathrm{d}$ of MR (DM) for $7 \mathrm{~d}$ (milk replacer high; MRH). The MR contained 25\% CP and 17\% fat (DM basis) and was based on whey proteins and lard as the primary fat source. Calves were fed their MR diluted to $14 \%$ $\mathrm{DM}$ in 2 equal morning and evening feedings, except for the last $3(\mathrm{MRM})$ or $7(\mathrm{MRH}) \mathrm{d}$, when calves were fed in the morning only. Reconstituted MR was fed in nipple pails. Calves were offered calf starter and water once per day at approximately $0900 \mathrm{~h}$ for ad libitum consumption throughout the trial.

Calves were housed in a curtain-sided, naturally ventilated barn with no added heat in $1.2-\times 2.4-\mathrm{m}$ individual wire pens bedded with straw. All animals were cared for as described in the Guide for the Care and Use of Agricultural Animals in Research and Teaching (FASS, 2010). The trial was conducted from June 1 to July 27, 2016.

Calves were weighed initially and every $7 \mathrm{~d}$ thereafter. Hip widths were measured with a caliper, and BCS was estimated initially and every $14 \mathrm{~d}$. Calf BCS was based on a 5-point system using 0.25-unit increments (1 = emaciated, $5=$ obese; Wildman et al., 1982). Scores were based on changes around the vertical and transverse processes of the spine as palpated by a single experienced technician. Starter intake offered and refused were measured daily, and the difference was assumed to be the starter intake. Feces were scored daily on a scale of 1 to 5 ( $1=$ firm, normal; $2=$ less firm, normal; $3=$ thick, batter-like; $4=$ thin, batter-like; $5=$ watery; modified from Kertz and Chester-Jones, 2004). An abnormal fecal day was recorded when the fecal score was $\geq 3$.

On d 2 to 5 and 15 to 18 , feces were collected from a subset of 5 calves randomly selected from each treatment group to estimate digestibility. During those $4 \mathrm{~d}$ and the preceding 1 or $7 \mathrm{~d}$ (for $\mathrm{d} 2$ to 5 and $\mathrm{d} 15$ to 18 , respectively), chromic oxide was added to the MR at each feeding as a digesta flow marker. Care was taken to ensure complete consumption of chromic oxide during the digestion period by remixing the MR immediately before feeding. Calves were rectally palpated by hand to obtain a fecal sample. Starter was sampled daily over $4 \mathrm{~d}$ and pooled, and MR powder was sampled. Pooled fecal samples were subsampled and analyzed for chro- 
mium in ashed samples relative to concentration in MR and feed over the 4-d period to estimate digestibility.

Composites of feeds, refused feed, and feces were analyzed for DM (oven method 930.15; AOAC International, 2000), ash (oven method 942.05; AOAC International, 2000), CP (Kjeldahl method 988.05; AOAC International, 2000), fat (alkaline treatment with Röse-Gottlieb method 932.06 for MR, diethyl ether extraction method 2003.05 for starters and hay; AOAC International, 2000), NDF with ash by the procedure of Van Soest et al. (1991) without sodium sulfite or $\alpha$-amylase, ADF with ash (Robertson and Van Soest, 1981), starch ( $\alpha$-amylase method; Hall, 2009), sugar (colorimetric method; Dubois et al., 1956), and Cr (Bouchard et al., 1973).

Treatments were analyzed as a completely randomized design with a $2 \times 2$ factorial arrangement of treatments (MC vs. CR; MRM vs. MRH) with calf as experimental unit, using the Mixed procedure of SAS (version 8; SAS Institute, Cary, NC). Calf was included as a random effect in the mixed model. Repeatedmeasures mixed models were used when variables were measured repeatedly:

$$
\mathrm{Y}_{\mathrm{ikl}}=\mu+\mathrm{T}_{\mathrm{i}}+\mathrm{W}_{\mathrm{k}}+\mathrm{TW}_{\mathrm{ik}}+\varepsilon_{\mathrm{ikl}}
$$

where $Y_{i k l}$ was observed response; $T_{i}$ was the fixed effect of treatment $i ; W_{k}$ was the repeated effect of time $\mathrm{k}$, which was modeled as an auto-regressive type 1 covariance matrix within experimental unit; $\mathrm{TW}_{\mathrm{ik}}$ was the interaction of treatment $\mathrm{i}$ and time $\mathrm{k}$; and $\varepsilon_{\mathrm{ikl}}$ was error using the Kenward-Roger procedures for determining degrees of freedom. Contrast statements were constructed to separate differences in MR intake, colostrum program, and interaction. Additional contrasts were constructed to evaluate $\mathrm{MR} \times$ week and colostrum program $\times$ week interactions. Differences were declared at $P \leq 0.05$ and tendencies at $P \leq 0.10$.

\section{RESULTS}

Average temperature at the experimental facility was $22^{\circ} \mathrm{C}$ with a range of 8 to $33^{\circ} \mathrm{C}$. Average relative humidity was $76 \%$ with a range of 17 to $100 \%$. The average temperature during the $3-\mathrm{d}$ calf collection period at the farm of origin was $23^{\circ} \mathrm{C}$, with a range of 15 to $32^{\circ} \mathrm{C}$. Several calves on both the CR and MC treatments died in the first $48 \mathrm{~h}$ and before transportation to the research facility. Calves on the MC treatment were replaced, but it was not possible to sample the colostrum fed to these calves during the first $24 \mathrm{~h}$. Calves on the $\mathrm{CR}$ treatment were not replaced. The composition of experimental feeds is shown in Table 1.
During the first $24 \mathrm{~h}$, calves were fed at $0.6 \pm 0.39 \mathrm{~h}$, $6.6 \pm 0.66 \mathrm{~h}$, and $12.5 \pm 0.72 \mathrm{~h}$ after birth. The colostrum replacer used in the study provided $159 \mathrm{~g}$ of IgG. Colostrum was collected from 18 of 29 lots of pooled colostrum used for MC treatments and contained 60.4 $\mathrm{g}$ of $\mathrm{IgG} / \mathrm{L}(\mathrm{SD}=18.56 ; \mathrm{n}=58)$ with a range of 0 to $93 \mathrm{~g} / \mathrm{L}$ (Table 2). Colostral protein and fat averaged $12.6 \pm 2.68 \%$ and $8.4 \pm 4.31 \%$, respectively. Intake of IgG and nutrients from MC and CR programs during the first $24 \mathrm{~h}$ of life is shown in Table 3. Colostral Brix concentration correlated 0.71 to colostrum IgG concentration measured by radial immunodiffusion; the regression equation was $\mathrm{IgG}=-27.27(\mathrm{SE}=11.65)+$ $3.945 \times$ Brix, $\%(\mathrm{SE}=0.52), P<0.001, \mathrm{R}^{2}=0.51$.

Calves fed MC consumed more $(P<0.001)$ IgG (Table 3$)$ and had higher $(P<0.01)$ serum total protein, Brix, and $\operatorname{IgG}$ concentrations than calves fed CR (Table 4). Neither AEA nor hematocrit differed among treatments. Initial serum protein was also greater $(P<$ 0.04) for calves fed MRM versus MRH.

Calves fed MC had greater final BW $(P<0.04)$ and ADG $(P<0.01)$ than calves fed CR. Also, calves fed MRH tended to have greater final BW $(P<0.06)$ and ADG $(P<0.09)$ than calves fed MRM. Change in hip width was greater $(P<0.001)$ and change in BCS tended to be greater $(P<0.06)$ when calves were fed MC compared with $\mathrm{CR}$. We found interactions between MR rate and colostrum treatments for initial and final BCS and for initial and final hip width. Calves fed MRM consumed more $(P<0.01)$ calf starter than calves fed MRH. Calves fed MC also consumed more $(P<0.05)$ calf starter than calves fed CR.

Calves fed CR had a greater $(P<0.04)$ number of days treated with veterinary medications than calves fed MC. At least 1 abnormal fecal day was recorded in

Table 1. Composition of feeds used in the trials

\begin{tabular}{lccc}
\hline Item & $\begin{array}{c}\text { Colostrum } \\
\text { replacer }\end{array}$ & $\begin{array}{c}\text { Milk } \\
\text { replacer }\end{array}$ & Starter $^{1}$ \\
\hline DM, \% & 95.0 & 96.9 & 87.1 \\
Content, \% of DM & 50.1 & 25.8 & 21.7 \\
CP & 20.9 & 17.6 & 3.3 \\
Fat & - & - & 7.6 \\
ADF & - & - & 15.7 \\
NDF & - & - & 6.3 \\
Sugar & - & 51.0 & - \\
Lactose & - & - & 37.4 \\
Starch & - & 5.6 & 7.2 \\
Ash & - & 0.73 & 1.18 \\
Calcium & - & 0.62 & 0.74 \\
Phosphorus & - & 0.10 & 0.45 \\
Magnesium & - & 1.50 & 1.23 \\
Potassium & - & 0.54 & 0.45 \\
Sodium & & &
\end{tabular}

${ }^{1}$ Textured calf starter containing $37 \%$ whole corn, $35 \%$ protein pellet, $25 \%$ whole oats, and $3 \%$ molasses.

${ }^{2}$ Calculated as 100 - protein - fat - ash (NRC, 2001). 
Table 2. Descriptive statistics for maternal colostrum (MC) fed to calves on MC treatment

\begin{tabular}{lccccc}
\hline Item & $\mathrm{N}$ & Mean & SD & Minimum & Maximum \\
\hline $\mathrm{pH}$ & 58 & 5.24 & 0.16 & 4.60 & 5.50 \\
Brix, \% & 58 & 22.2 & 3.36 & 11.0 & 29.0 \\
$\mathrm{IgG}, \mathrm{g} / \mathrm{L}$ & 58 & 60.4 & 18.56 & 0.0 & 92.6 \\
$\mathrm{DM}, \%$ & 56 & 27.9 & 4.60 & 18.4 & 36.0 \\
Fat, \% & 56 & 8.4 & 4.31 & 1.9 & 18.3 \\
Protein, \% & 56 & 12.6 & 2.68 & 2.8 & 18.2 \\
Lactose, \% & 56 & 3.0 & 0.78 & 2.1 & 6.8 \\
Osmolality, mOsm/kg & 56 & 332.0 & 29.15 & 246.0 & 443.1 \\
SCC, $\log _{10} \mathrm{cfu} / \mathrm{mL}$ & 53 & 5.28 & 0.756 & 3.00 & 7.27 \\
\hline
\end{tabular}

17 calves $(4,4,4$, and 5 calves in MC-MRM, CR-MRM, $\mathrm{MC}-\mathrm{MRH}$, and CR-MRH, respectively).

Least squares means (LSM) of weekly BW were affected by treatment, week, and a treatment $\times$ week interaction (Figure 1). Calves fed MC-MRH had greater $(P<0.05)$ BW compared with calves fed MC-MRM during wk 1 and 2; thereafter, BW of calves fed MCMRH were greater $(P<0.05)$ than BW of calves on all other treatments to wk 8 .

Weekly LSM of ADG (Figure 2) were affected by a week, treatment, and treatment $\times$ week interaction. During wk 1 to 3 , calves fed MC-MRH gained more $(P$ $<0.05)$ than calves fed CR-MRM. Also, calves fed MC$\mathrm{MRH}$ gained more $(P<0.05) \mathrm{BW}$ than calves fed MCMRM at wk 3. At wk 4, calves fed CR-MRH gained more $(P<0.05)$ than calves fed CR-MRM. Calves fed CR-MRM gained less $(P<0.05)$ than other calves during wk 5 . Finally, during wk 7 , calves fed MRM gained more $(P<0.05)$ BW than calves fed MRH.

Calf starter intake was affected by treatment, week, and a treatment $\times$ week interaction. Starter intake (Figure 3) was low in all calves until wk 5; thereafter, intake increased $(P<0.001)$ as the amount of MR offered was reduced to weaning on $\mathrm{d} 42$. Starter intake was lower $(P<0.05)$ in calves fed MRH compared with calves fed MC-MRM at wk 6 and lower $(P<0.05)$ in calves fed CR-MRH than other treatments during wk 7 to 8 .

Digestibilities of DM, OM, CP, and fat (Table 5) were unaffected by age or treatment, although the digestibility of DM tended $(P<0.08)$ to be affected by a treatment $\times$ week interaction and digestibility of fat tended to be affected by week $(P<0.07)$.

\section{DISCUSSION}

Although AEA did not differ by treatment, both measures of AEA were lower than other reports for maternal colostrum or replacers in the literature (Quigley et al., 2001, 2017; Pithua et al., 2013; Lago et al., 2018). It was expected that AEA in calves fed MC would be low, because 2 feedings occurred at 6 and $12 \mathrm{~h}$, when cessation of macromolecular transport was underway in the intestine (Bush and Staley, 1980). However, lower AEA in calves fed CR were unexpected, because the CR was fed only once during the first hour of life. Calves on the $\mathrm{CR}$ treatment were fed colostrum replacer followed by commercial MR at 6 and $12 \mathrm{~h}$ postpartum so that they were fed only 1 dose of colostrum replacer and were provided limited amounts of $\operatorname{IgG}$ and nutrients compared with the MC treatment but with a similar feeding schedule. We hypothesize that intubation of $\mathrm{MR}$ at 6 and $12 \mathrm{~h}$ following initial feeding of colostrum replacer delayed abomasal outflow and may have diluted the IgG in the colostrum replacer, so that AEA and serum IgG were reduced. Mokhber-Dezfooli et al. (2012) reported that abomasal outflow explained $22 \%$ of the variation in AEA, and slowing abomasal outflow decreased AEA linearly by $>70 \%$. Intubation has also been shown to slow abomasal emptying (Nouri and Constable, 2006; Burgstaller et al., 2017) compared to suckling. Desjardins-Morrissette et al. (2018) reported little effect of administration of $3 \mathrm{~L}$ of colostrum on abomasal emptying and suggested that residual colostrum in the rumen may be responsible for delays in abomasal outflow when colostrum is administered by esophageal feeder. The amount of colostrum remaining in the rumen (assumed to be fixed based on the size of the animal) would be proportionally greater when smaller volumes are fed and thus have a greater effect on the observed abomasal emptying.

Osmolality of MR is generally higher than that of cow milk (Constable et al., 2005) or colostrum, which

Table 3. Nutrient and IgG intake $(\mathrm{g})$ in calves fed maternal colostrum $(\mathrm{MC})$ or colostrum replacer plus milk replacer $(\mathrm{CR})$ during the first $24 \mathrm{~h}$

\begin{tabular}{lrrl}
\hline Item & MC & SD & CR \\
\hline IgG & 343 & 105.2 & 159 \\
DM & 1,583 & 260.5 & 915 \\
Protein & 718 & 151.8 & 368 \\
Fat & 474 & 244.6 & 184 \\
Lactose $^{1}$ & 169 & 44.0 & 312 \\
\hline Calo
\end{tabular}

${ }^{1}$ Calculated as 100 - protein - fat - ash (NRC, 2001). 
Table 4. Least squares means of serum variables and performance of calves fed different sources of colostrum and amounts of milk replacer (0 to $56 \mathrm{~d})$

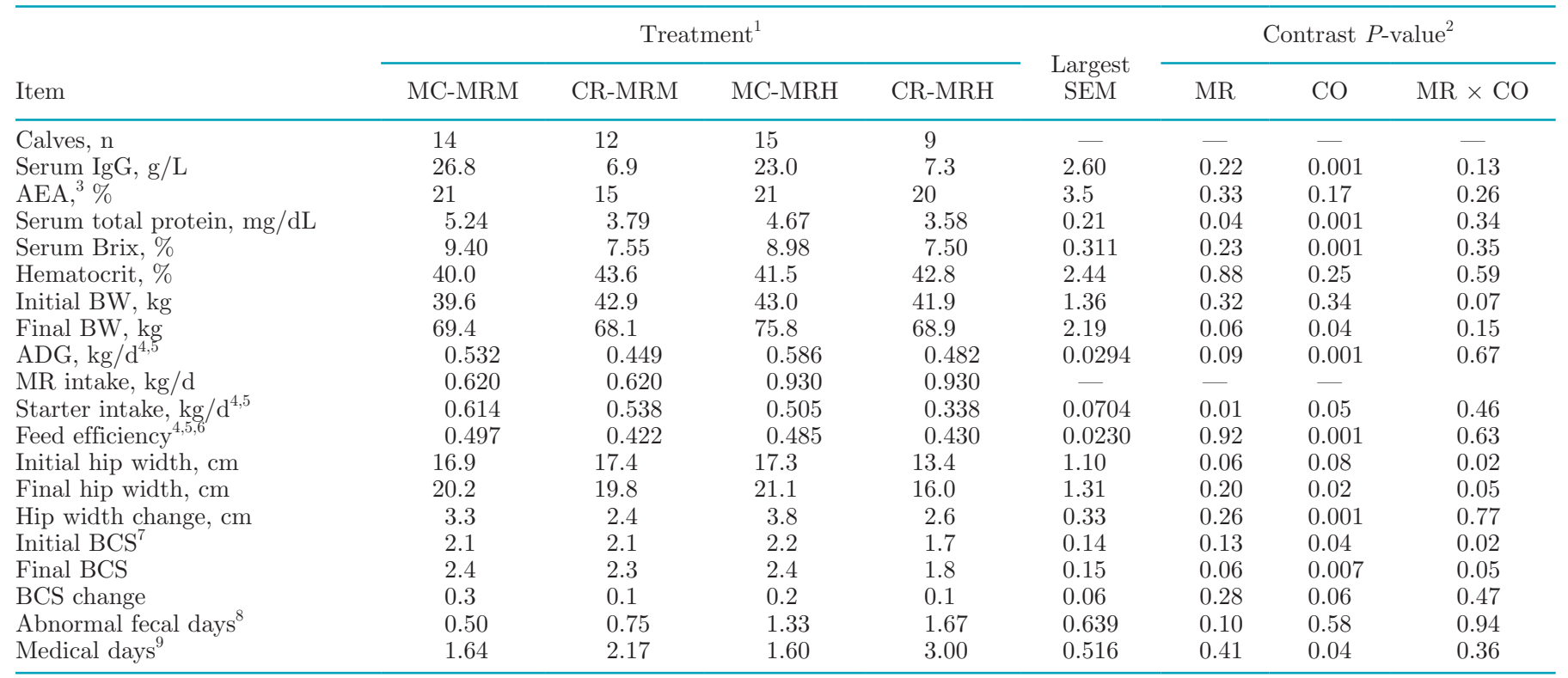

${ }^{1} \mathrm{MC}=$ maternal colostrum for 3 feedings; $\mathrm{CR}=$ colostrum replacer for the first feeding, followed by milk replacer (MR) for 2 feedings; MRM $=0.66 \mathrm{~kg} / \mathrm{d}$ MR (DM) for $39 \mathrm{~d}$, then $0.33 \mathrm{~kg} / \mathrm{d} \mathrm{MR}(\mathrm{DM})$ for $3 \mathrm{~d} ; \mathrm{MRH}=0.77 \mathrm{~kg} / \mathrm{d}$ MR (DM) for $13 \mathrm{~d}$, then $1.03 \mathrm{~kg} / \mathrm{d} \mathrm{MR}(\mathrm{DM})$ for $22 \mathrm{~d}$, then $0.51 \mathrm{~kg} / \mathrm{d} \mathrm{MR}(\mathrm{DM})$ for $7 \mathrm{~d}$.

${ }^{2}$ Probability of an effect of MR, colostrum $(\mathrm{CO})$, or $\mathrm{MR} \times \mathrm{CO}$ interaction.

${ }^{3} \mathrm{AEA}=$ apparent efficiency of IgG absorption.

${ }^{4}$ Significant effect of week $(P<0.001)$.

${ }^{5}$ Significant week $\times$ treatment interaction $(P<0.01)$.

${ }^{6} \mathrm{BW}$ gain divided by MR plus starter intake.

${ }^{7}$ Body condition score: $1=$ emaciated to $5=$ obese.

${ }^{8}$ Total days with fecal score $\geq 3$.

${ }^{9}$ Total days that animal was treated with veterinary drugs.

may also reduce the rate of abomasal emptying. It is possible that a combination of intubation, higher osmolality of colostrum replacer and MR, and frequent feeding schedule (3 times in the first $24 \mathrm{~h}$ ) reduced outflow from the abomasum and negatively affected absorption of IgG and other biologically active molecules from the colostrum replacer. Conversely, Cabral et al. (2014) reported no effect of feeding MR $6 \mathrm{~h}$ after feeding 1 or 2 feedings of colostrum replacer. However, most calves in this study consumed colostrum replacer by nipple bottle, which would bypass the rumen and enter the abomasum, and were subsequently tube-fed MR, which would enter the rumen. Differences in method of feeding between our study and that of Cabral et al. (2014) may explain the different effects of feeding MR in these studies. Although we hypothesized that the $\mathrm{CR}$ program affected absorption of IgG via changes in abomasal osmolality, we did not measure abomasal outflow rates, and confirmation awaits further research.

Predisposition to disease in neonates depends not only on acquisition of passive immunity but also on exposure to potential pathogens (Quigley et al., 2017).
In some studies, in which calves were fed colostrum replacer, replacer feeding had no effect on the incidence or severity of disease compared with calves fed maternal colostrum (Quigley et al., 2001; Swan et al., 2007; Lago et al., 2018), although others (Priestley et al., 2013) reported increased morbidity or mortality when colostrum replacer was fed instead of maternal colostrum. In the present study, some calves experienced respiratory disease, which occurred to a greater extent in calves fed CR (greater number of days with veterinary treatments). Following the first $48 \mathrm{~h}$, the study had no mortality.

Numerous studies have evaluated effects of colostrum replacers on serum IgG concentration, AEA, and incidence of preweaning disease, often with markedly different results. Colostrum products contain different IgG sources (plasma or colostrum), methods of manufacturing, amount of IgG per dose, and feeding recommendations; therefore, it is expected that results for the efficacy of these products would vary. Serum IgG concentrations were generally greater when calves were fed high-quality maternal colostrum compared 


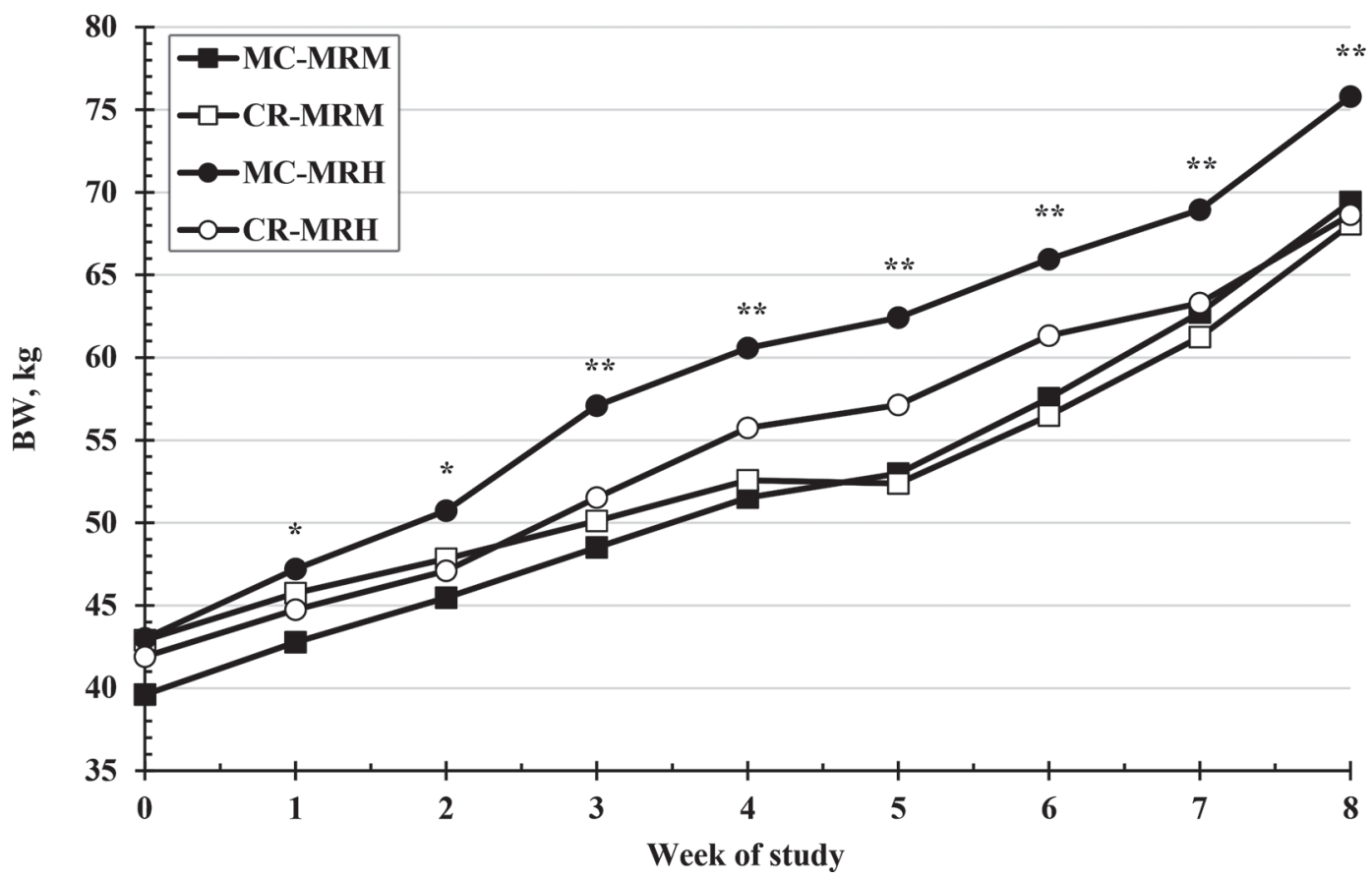

Figure 1. Least squares means of BW in calves fed maternal colostrum for 3 feedings (MC); colostrum replacer for the first feeding followed by milk replacer (MR) for 2 feedings $(\mathrm{CR}) ; 0.66 \mathrm{~kg} / \mathrm{d}$ MR (DM) for $39 \mathrm{~d}$, then $0.33 \mathrm{~kg} / \mathrm{d}$ MR (DM) for $3 \mathrm{~d}(\mathrm{MRM})$; or $0.77 \mathrm{~kg} / \mathrm{d} \mathrm{MR}(\mathrm{DM})$ for $13 \mathrm{~d}$, then $1.03 \mathrm{~kg} / \mathrm{d}$ MR $(\mathrm{DM})$ for $22 \mathrm{~d}$, then $0.51 \mathrm{~kg} / \mathrm{d}$ MR $(\mathrm{DM})$ for $7 \mathrm{~d}(\mathrm{MRH})$. SEM $=1.04$ to 2.05 . $*$ MC-MRH $>$ MC-MRM, P $<0.05$. ** MC-MRH $>$ other treatments, $P<0.05$.

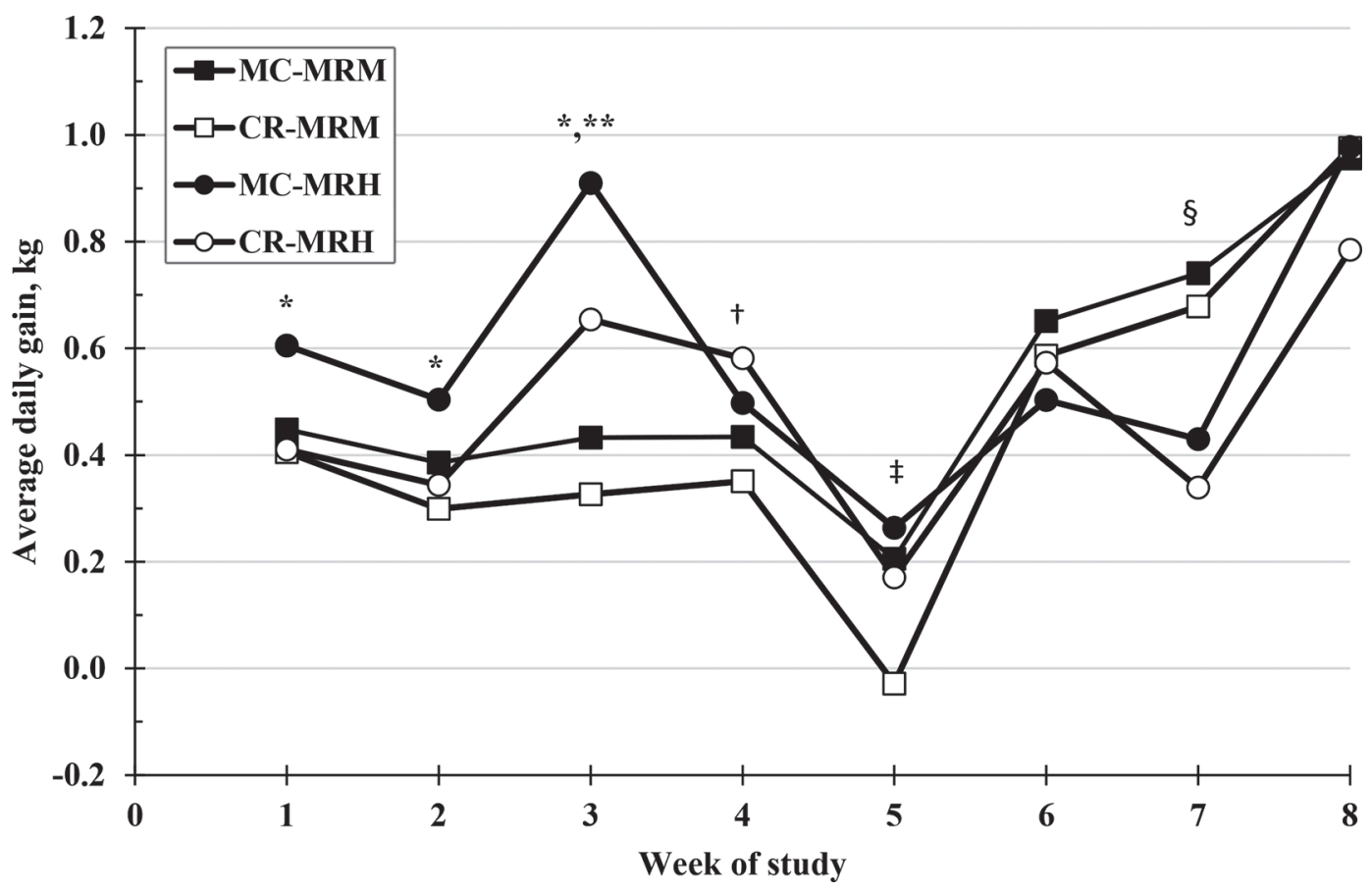

Figure 2. Least squares means of ADG in calves fed maternal colostrum for 3 feedings (MC); colostrum replacer for the first feeding followed by milk replacer (MR) for 2 feedings $(\mathrm{CR}) ; 0.66 \mathrm{~kg} / \mathrm{d} \mathrm{MR}(\mathrm{DM})$ for $39 \mathrm{~d}$, then $0.33 \mathrm{~kg} / \mathrm{d}$ MR (DM) for $3 \mathrm{~d}(\mathrm{MRM}) ;$ or $0.77 \mathrm{~kg} / \mathrm{d} \mathrm{MR}(\mathrm{DM})$ for $13 \mathrm{~d}$, then $1.03 \mathrm{~kg} / \mathrm{d}$ MR $(\mathrm{DM})$ for $22 \mathrm{~d}$, then $0.51 \mathrm{~kg} / \mathrm{d}$ MR $(\mathrm{DM})$ for $7 \mathrm{~d}(\mathrm{MRH})$. SEM $=1.04$ to 2.05 . ${ }^{*} \mathrm{MC}-\mathrm{MRH}>\mathrm{CR}-\mathrm{MRM}, P<0.05$. **MC-MRH $>$ MC-MRM, $P<0.05$. †CR-MRH $>$ CR-MRM, $P<0.05$. †CR-MRM $<$ other treatments, $P<0.05 . \S$ MRM $>$ MRH, $P<0.05$. 


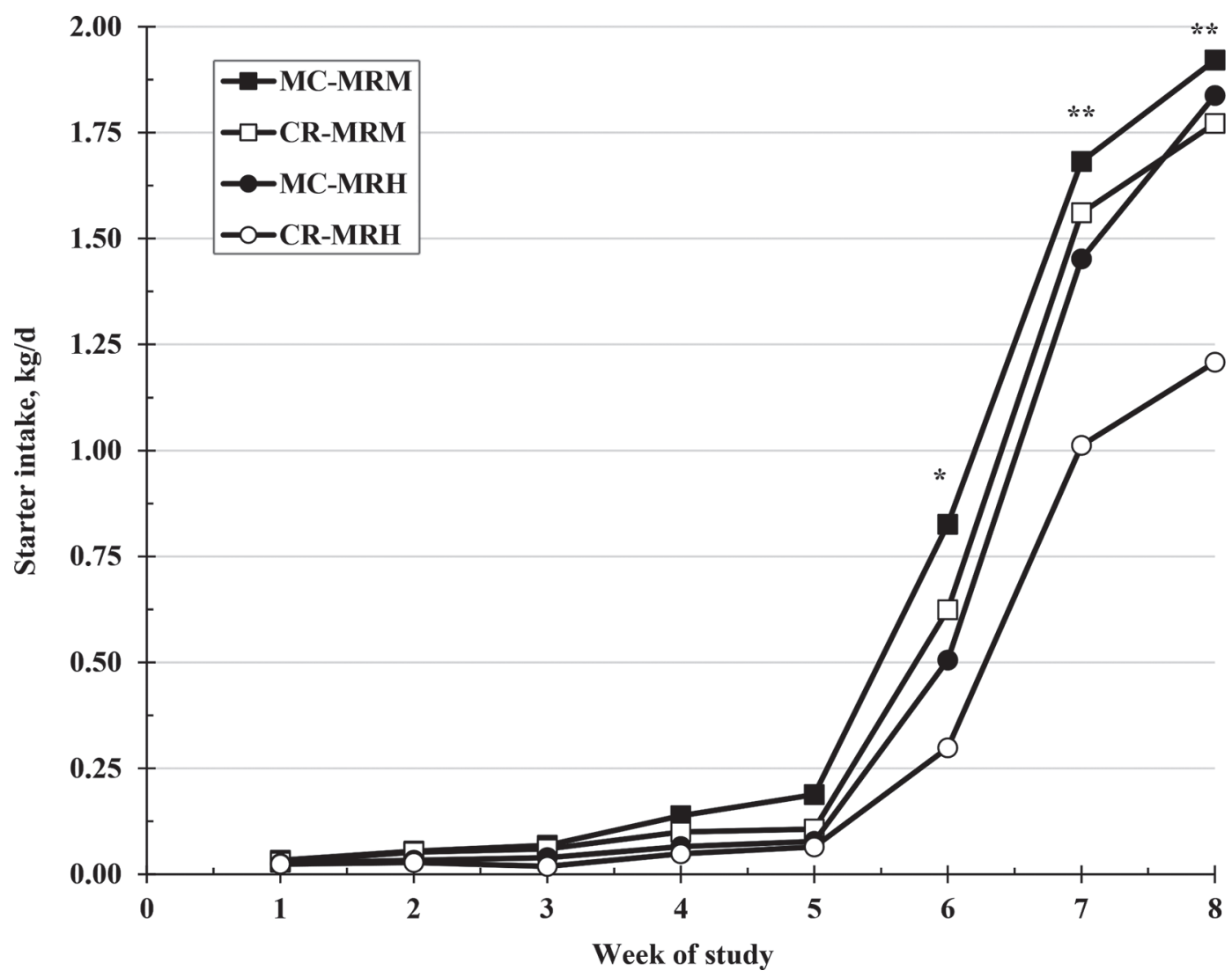

Figure 3. Least squares means of starter intake in calves fed maternal colostrum for 3 feedings (MC); colostrum replacer for the first feeding followed by milk replacer (MR) for 2 feedings (CR); $0.66 \mathrm{~kg} / \mathrm{d}$ MR (DM) for $39 \mathrm{~d}$, then $0.33 \mathrm{~kg} / \mathrm{d} \mathrm{MR}$ (DM) for $3 \mathrm{~d}$ (MRM); or $0.77 \mathrm{~kg} / \mathrm{d}$ MR $(\mathrm{DM})$ for $13 \mathrm{~d}$, then $1.03 \mathrm{~kg} / \mathrm{d} \mathrm{MR}(\mathrm{DM})$ for $22 \mathrm{~d}$, then $0.51 \mathrm{~kg} / \mathrm{d}$ MR $(\mathrm{DM})$ for $7 \mathrm{~d}(\mathrm{MRH})$. SEM = 1.04 to 2.05 . *MC-MRM > CR-MRH, MC-MRH, $P<0.05 .{ }^{*}$ CR-MRH $<$ other treatments, $P<0.05$.

with colostrum replacers (Quigley et al., 2001; Foster et al., 2006; Fidler et al., 2011), whereas concentrations were similar when poor-quality colostrum was used (Aly et al., 2013; Pithua et al., 2013). Other factors may affect serum IgG concentration in calves fed replacers, such as the method of manufacturing (Quigley et al., 2001; Campbell et al., 2007). Variation in other experimental factors such as the dose of the product fed and feeding via esophageal feeder or nipple bottle may also influence absorption efficiency (Godden et al., 2009a,b).

The ability of an animal to use nutrients for growth depends on nutrient intake above maintenance requirements, as well as their immune status and need to use nutrients to support an immune response after an immunological challenge. In this study, calves fed MRH were given sufficient nutrients before weaning to grow more rapidly than calves fed MRM. Thus, calves fed MRH should have been consistently heavier and with greater structural growth, at least before weaning. However, calves fed CR-MRH grew similarly to calves fed CR-MRM and MC-MRM throughout the study, suggesting that additional nutrients in the liquid feed were not used efficiently. Lower feed efficiency in calves fed CR supports this hypothesis.

Disease states may induce anorexia and redirect nutrients away from growth (Johnson, 1997; Spurlock, 1997). Calves fed CR had greater incidence of respiratory disease and required more veterinary treatments during the trial. Further, these calves had less change in hip width and BCS, indicating reduced structural growth and fattening during the trial.

Calves fed MRH consumed less calf starter but tended to have greater final (56-d) BW (Figure 1) and ADG (Figure 2) than calves fed MRM. Differences in growth were similar to some reports (Dennis et al., 2018) in which moderate and high amounts of MR were fed, but not as great as others (Quigley et al., 2018; Dennis et al., 2019). It should be noted that calves on MC-MRM tended $(P<0.07)$ to be lighter at initiation of the trial (Table 4); therefore, BW in this group tended to be less during the first $4 \mathrm{wk}$ of the trial, although BW gains were similar to those of calves fed CR-MRM and CR-MRH (Figure 2). 
Table 5. Least squares means of BW, milk replacer intake and digestibility of selected nutrients in calves during d 2-5 (wk 1) and d 15-18 (wk 3)

\begin{tabular}{|c|c|c|c|c|c|c|c|c|c|c|}
\hline Item & \multicolumn{4}{|c|}{ Treatment $^{1}$} & SEM & Week & $\mathrm{W} \times \mathrm{T}^{2}$ & \multicolumn{3}{|c|}{ Contrast $P$-value ${ }^{3}$} \\
\hline $\mathrm{BW}, \mathrm{kg}$ & & & & & & 0.001 & 0.001 & 0.65 & 0.59 & 0.14 \\
\hline Week 3 & 46.9 & 49.6 & 51.3 & 49.3 & 1.88 & & & & & \\
\hline Overall & 43.9 & 47.8 & 47.7 & 45.8 & 1.89 & & & & & \\
\hline MR intake, $\%$ of $\mathrm{BW}$ & & & & & & 0.001 & 0.001 & 0.001 & 0.85 & 0.12 \\
\hline Overall & 1.52 & 1.39 & 2.01 & 2.11 & 0.068 & & & & & \\
\hline Digestibility, \% & & & & & & & & & & \\
\hline DM & & & & & & 0.31 & 0.08 & 0.87 & 0.23 & 0.80 \\
\hline Week 1 & 90.6 & 92.1 & 92.9 & 93.0 & 1.36 & & & & & \\
\hline Week 3 & 93.7 & 93.3 & 91.2 & 93.0 & 0.83 & & & & & \\
\hline Overall & 92.1 & 92.7 & 92.1 & 93.0 & 0.78 & & & & & \\
\hline $\mathrm{OM}$ & & & & & & 0.89 & 0.27 & 0.57 & 0.35 & 0.56 \\
\hline Week 3 & 88.3 & 86.5 & 82.8 & 87.9 & 2.12 & & & & & \\
\hline Overall & 85.9 & 85.0 & 85.2 & 87.5 & 2.06 & & & & & \\
\hline Ether extract & & & & & & 0.07 & 0.59 & 0.30 & 0.27 & 0.37 \\
\hline Week 1 & 97.0 & 95.0 & 96.0 & 95.3 & 1.12 & & & & & \\
\hline Week 3 & 97.5 & 97.0 & 96.1 & 96.6 & 0.68 & & & & & \\
\hline Overall & 97.2 & 96.0 & 96.1 & 96.0 & 0.68 & & & & & \\
\hline
\end{tabular}

${ }^{1} \mathrm{MC}=$ maternal colostrum for 3 feedings; $\mathrm{CR}=$ colostrum replacer for the first feeding, followed by milk replacer (MR) for 2 feedings; MRM $=0.66 \mathrm{~kg} / \mathrm{d} \mathrm{MR}(\mathrm{DM})$ for $39 \mathrm{~d}$, then $0.33 \mathrm{~kg} / \mathrm{d} \mathrm{MR}(\mathrm{DM})$ for $3 \mathrm{~d} ; \mathrm{MRH}=0.77 \mathrm{~kg} / \mathrm{d} \mathrm{MR}(\mathrm{DM})$ for $13 \mathrm{~d}$, then $1.03 \mathrm{~kg} / \mathrm{d} \mathrm{MR}(\mathrm{DM})$ for $22 \mathrm{~d}$, then $0.51 \mathrm{~kg} / \mathrm{d}$ MR $(\mathrm{DM})$ for $7 \mathrm{~d}$.

${ }^{2}$ Week $\times$ treatment interaction.

${ }^{3}$ Probability of an effect of $\mathrm{MR}$, colostrum $(\mathrm{CO})$, or $\mathrm{MR} \times \mathrm{CO}$ interaction.

Estimates of apparent total-tract digestibility in this study during the first and third weeks of life compared favorably with data in calves fed MR (Jenkins et al., 1985; Blome et al., 2003; Liang et al., 2016) or whole milk (Russell et al., 1980) but were greater than those in other studies with older calves fed dry feed (Huuskonen et al., 2005). The relative lack of change with advancing age was inconsistent with the conclusions of some studies (Radostits and Bell, 1968; Arieli et al., 1995; Guilloteau et al., 2009) but supported other findings (Liang et al., 2016). We note that the calves from which digestibility measurements were taken had access to calf starter during the digestibility measurement periods at 1 and 3 wk, which could have confounded our results, because digestibility measurements using chromic oxide estimated the apparent nutrient digestibility of the total diet, including both MR and calf starter. Calves fed MRM consumed an average of 4 and $9 \%$ of total DM as starter during wk 1 and 3, respectively, whereas calves fed MRH consumed 3 and $3 \%$ of total DM as starter, respectively, at 1 and $3 \mathrm{wk}$. However, the lack of difference among treatments and week supports the hypothesis that dry feed consumption did not markedly affect digestibility measurements. Lack of treatment difference in calves fed MC or CR indicates that level of passive immunity had no effect on digestibility measurements. This observation does not support the findings of Arieli et al. (1995), who reported that serum IgG was positively correlated with $\mathrm{N}$ and energy digestibility during the digestibility trial.

Radostits and Bell (1968) reported increasing digestibility of nutrients in calves with age in calves fed MR from 6 to $24 \mathrm{~d}$ of age. Digestibility of DM increased from 74 to $89 \%$ from 6 to 24 d; during the same period, CP digestibility increased from 63 to $84 \%$ and fat digestibility increased from 29 to $82 \%$. The authors noted that calves had temporary diarrhea characterized by soft feces during the first week that may have been responsible for lower digestibility. Higher digestion of DM and fat in our study may have been related to improved methods of manufacturing of feeds in our study and the inclusion of oat groats in the MR fed by Radostits and Bell (1968).

Calves in the study of Arieli et al. (1995) were transported immediately before the trial started and were fed MR at 70 and $110 \%$ of the ME requirements for maintenance, at ambient temperatures of 7.5 or $19^{\circ} \mathrm{C}$, over 2 consecutive but separately monitored 7-d balance periods. The overall digestibilities of $\mathrm{N}$ and energy were 78 and $89 \%$, respectively, over the 2 -wk trial. Be- 
tween wk 1 and 2, $\mathrm{N}$ and energy digestibility increased 8.5 and $4.7 \%$, respectively. Mean digestibilities in our study were higher than estimates of Arieli et al. (1995). Terosky et al., (1997) also reported lower nutrient digestibility in calves fed MR at 2 wk of age compared with that at 4,6 , or 8 wk of age. However, the authors reported significant incidence of diarrhea in calves at 2 wk.

The conclusion that digestion early in life is limited may be due at least in part to stress and diarrhea in these published studies. Our data, as well as the data of Liang et al. (2016), suggest that total-tract digestibility of nutrients is well developed within the first week of life and independent of colostrum or MR intake. Further, calves fed $\mathrm{CR}$ received 1 feeding of reconstituted colostrum plus 2 feedings of MR compared with calves fed MC, which received 3 colostrum feedings in the first 24 h. Blättler et al. (2001) reported that feeding large amounts of maternal colostrum enhanced the survival of epithelial cells in the small intestine, whereas limited colostrum administration reduced epithelial growth. The lack of difference in nutrient digestibility in calves fed $\mathrm{MC}$ or $\mathrm{CR}$ in our study suggests that the differences reported by Blättler et al. (2001) may be insufficient to alter total-tract nutrient digestibility in the first $3 \mathrm{wk}$ of life.

\section{CONCLUSIONS}

Calves fed $\mathrm{CR}$ in our study achieved lower-thanexpected serum IgG concentrations at $24 \mathrm{~h}$ of life, likely due to additional feedings of MR that occurred at 6 and $12 \mathrm{~h}$ of age. Subsequent differences in serum IgG, Brix, and total protein were indicative of differential acquisition of passive immunity and increased susceptibility to disease in these calves. The effects of differences in colostrum feeding program were manifested throughout the 56-d feeding period. Calves fed more MR generally grew faster, but colostral status influenced growth, feed intake, and feed efficiency without affecting nutrient digestion.

\section{ACKNOWLEDGMENTS}

The authors acknowledge the assistance of R. Schlotterbeck and the farm staff at the Nurture Research Center for animal care and sample collection. This research was funded by Provimi, a division of Cargill Animal Nutrition.

\section{REFERENCES}

Aly, S. S., P. Pithua, J. D. Champagne, and D. M. Haines. 2013. A randomized controlled trial on preweaning morbidity, growth and mortality in Holstein heifers fed a lacteal-derived colostrum replacer or pooled maternal colostrum. BMC Vet. Res. 9:168-174.

AOAC International. 2000. Official Methods of Analysis. Vol. I. 17th ed. AOAC International, Arlington, VA.

Arieli, A., J. W. Schrama, W. Van Der Hel, and M. W. A. Verstegen. 1995. Development of metabolic partitioning of energy in young calves. J. Dairy Sci. 78:1154-1162.

Blättler, U., H. M. Hammon, C. Morel, C. Philipona, A. Rauprich, V. Rome, I. Le Huerou-Luron, P. Guilloteau, and J. W. Blum. 2001. Feeding colostrum, its composition and feeding duration variably modify proliferation and morphology of the intestine and digestive enzyme activities of neonatal calves. J. Nutr. 131:1256-1263.

Blome, R. M., J. K. Drackley, F. K. McKeith, M. F. Hutjens, and G. C. McCoy. 2003. Growth, nutrient utilization, and body composition of dairy calves fed milk replacers containing different amounts of protein. J. Anim. Sci. 81:1641-1655.

Bouchard, R., G. J. Brisson, and J. P. Julien. 1973. Nutritive value of bacterial sludge and whey powders for protein in calf milk replacers and on chromic oxide as indicator of digestibility. J. Dairy Sci. 56:1445-1449.

Burgstaller, J., T. Wittek, and G. W. Smith. 2017. Invited review: Abomasal emptying in calves and its potential influence on gastrointestinal disease. J. Dairy Sci. 100:17-35.

Bush, L. J., and T. E. Staley. 1980. Absorption of colostral immunoglobulins in newborn calves. J. Dairy Sci. 63:672-680.

Cabral, R. G., M. A. Cabral, C. E. Chapman, E. J. Kent, D. M. Haines, and P. S. Erickson. 2014. Colostrum replacer feeding regimen, addition of sodium bicarbonate, and milk replacer: The combined effects on absorptive efficiency of immunoglobulin $\mathrm{G}$ in neonatal calves. J. Dairy Sci. 97:2291-2296.

Campbell, J. M., L. E. Russell, J. D. Crenshaw, E. M. Weaver, S. Godden, J. D. Quigley, J. Coverdale, and H. Tyler. 2007. Impact of irradiation and immunoglobulin $\mathrm{G}$ concentration on absorption of protein and immunoglobulin $\mathrm{G}$ in calves fed colostrum replacer. J. Dairy Sci. 90:5726-5731.

Constable, P. D., A. F. Ahmed, and N. A. Misk. 2005. Effect of suckling cow's milk or milk replacer on abomasal luminal $\mathrm{pH}$ in dairy calves. J. Vet. Intern. Med. 19:97-102.

Dennis, T. S., F. X. Suarez-Mena, T. M. Hill, J. D. Quigley, R. L. Schlotterbeck, R. N. Klopp, G. J. Lascano, and L. Hulbert. 2018. Effects of gradual and later weaning ages when feeding high milk replacer rates on growth, textured starter digestibility, and behavior in Holstein calves from 0 to 4 months of age. J. Dairy Sci. 101:9863-9875.

Dennis, T. S., F. X. Suarez-Mena, W. Hu, T. M. Hill, J. D. Quigley, and R. L. Schlotterbeck. 2019. Effects of milk replacer feeding rate and long-term antibiotic inclusion in milk replacer on performance and nutrient digestibility of Holstein dairy calves up to 4 months of age. J. Dairy Sci. 102:2094-2102.

Desjardins-Morrissette, M., J. K. van Niekerk, D. Haines, T. Sugino, M. Oba, and M. A. Steele. 2018. The effect of tube versus bottle feeding colostrum on immunoglobulin $\mathrm{G}$ absorption, abomasal emptying, and plasma hormone concentrations in newborn calves. J. Dairy Sci. 101:4168-4179.

Dubois, M., K. A. Gilles, J. K. Hamilton, P. A. Rebers, and F. Smith. 1956. Colorimetric method for determination of sugars and related substances. Anal. Chem. 28:350-356.

FASS. 2010. Guide for the Care and Use of Agricultural Animals in Agricultural Research and Teaching. 3rd ed. Federation of Animal Science Societies, Champaign, IL.

Fidler, A. P., M. L. Alley, and G. W. Smith. 2011. Short communication: Serum immunoglobulin G and total protein concentrations in dairy calves fed a colostrum-replacement product. J. Dairy Sci. 94:3609-3612.

Foster, D. M., G. W. Smith, T. R. Sanner, and G. V. Busso. 2006 Serum IgG and total protein concentrations in dairy calves fed two colostrum replacement products. J. Am. Vet. Med. Assoc. 229:1282-1285.

Godden, S. M., D. M. Haines, and D. Hagman. 2009a. Improving passive transfer of immunoglobulins in calves. I: Dose effect of feeding a commercial colostrum replacer. J. Dairy Sci. 92:1750-1757. 
Godden, S. M., D. M. Haines, K. Konkol, and J. Peterson. 2009b. Improving passive transfer of immunoglobulins in calves. II: Interaction between feeding method and volume of colostrum fed. J. Dairy Sci. 92:1758-1764.

Guilloteau, P., R. Zabielski, and J. W. Blum. 2009. Gastrointestinal tract and digestion in the young ruminant: Ontogenesis, adaptations, consequences and manipulations. J. Physiol. Pharmacol. 60(Suppl. 3):37-46.

Hall, M. B. 2009. Analysis of starch, including maltooligosaccharides, in animal feeds: A comparison of methods and a method recommended for AOAC collaborative study. J. AOAC Int. 92:42-49.

Hammon, H. M., J. Steinhoff-Wagner, U. Schönhusen, C. C. Metges, and J. W. Blum. 2012. Energy metabolism in the newborn farm animal with emphasis on the calf: Endocrine changes and responses to milk-born and systemic hormones. Domest. Anim. Endocrinol. 43:171-185.

Huuskonen, A., H. Khalili, J. Kiljala, E. Joki-Tokola, and J. Nousiainen. 2005. Effects of vegetable fats versus lard in milk replacers on feed intake, digestibility, and growth in Finnish Ayrshire bull calves. J. Dairy Sci. 88:3575-3581.

Jenkins, K. J., K. G. Kramer, F. D. Sauer, and D. B. Emmons. 1985. Influence of triglycerides and free fatty acids in milk replacers on calf performance, blood plasma, and adipose lipids. J. Dairy Sci. 68:669-680.

Johnson, R. W. 1997. Inhibition of growth by pro-inflammatory cytokines: An integrated view. J. Anim. Sci. 75:1244-1255.

Jones, C. M., R. E. James, J. D. Quigley III, and M. L. McGilliard. 2004. Influence of pooled colostrum or colostrum replacement on IgG and evaluation of animal plasma in milk replacer. J. Dairy Sci. 87:1806-1814

Kertz, A. F., and H. Chester-Jones. 2004. Invited review: Guidelines for measuring and reporting calf and heifer experimental data. J. Dairy Sci. 87:3577-3580.

Lago, A., M. Socha, A. Geiger, D. Cook, N. Silva-del-Río, C. Blanc, R. Quesnell, and C. Leonardi. 2018. Efficacy of colostrum replacer versus maternal colostrum on immunological status, health, and growth of preweaned dairy calves. J. Dairy Sci. 101:1344-1354.

Liang, Y., J. A. Carroll, and M. A. Ballou. 2016. The digestive system of 1-week-old Jersey calves is well suited to digest, absorb, and incorporate protein and energy into tissue growth even when calves are fed a high plane of milk replacer. J. Dairy Sci. 99:1929-1937.

Løkke, M. M., R. Engelbrecht, and L. Wiking. 2016. Covariance structures of fat and protein influence the estimation of IgG in bovine colostrum. J. Dairy Res. 83:58-66.

Mee, J. F., K. J. O'Farrell, P. Reitsma, and R. J. Mehr. 1996. Effect of a whey protein concentrate used as a colostrum substitute or supplement on calf immunity, weight gain, and health. J. Dairy Sci. 79:886-894.

Mokhber-Dezfooli, M. R., M. Nouri, M. Rasekh, and P. D. Constable. 2012. Effect of abomasal emptying rate on the apparent efficiency of colostral immunoglobulin G absorption in neonatal HolsteinFriesian calves. J. Dairy Sci. 95:6740-6749.

Nouri, M., and P. D. Constable. 2006. Comparison of two oral electrolyte solutions and route of administration on the abomasal emptying rate of Holstein-Friesian calves. J. Vet. Intern. Med. 20:620-626.

NRC. 2001. Nutrient Requirements of Dairy Cattle. 7th rev. ed. Natl. Acad. Sci., Washington, DC.

Pithua, P., S. S. Aly, D. M. Haines, J. D. Champagne, J. R. Middleton, and S. E. Poock. 2013. Efficacy of feeding a lacteal-derived colostrum replacer or pooled maternal colostrum with a low $\mathrm{IgG}$ concentration for prevention of failure of passive transfer in dairy calves. J. Am. Vet. Med. Assoc. 243:277-282.

Priestley, D., J. H. Bittar, L. Ibarbia, C. A. Risco, and K. N. Galvão. 2013. Effect of feeding maternal colostrum or plasma-derived or colostrum-derived colostrum replacer on passive transfer of immunity, health, and performance of preweaning heifer calves. J. Dairy Sci. 96:3247-3256.

Quigley, J. D., III, J. J. Drewry, and K. R. Martin. 1998. Estimation of plasma volume in Holstein and Jersey calves. J. Dairy Sci. 81:1308-1312.
Quigley, J. D., T. M. Hill, L. L. Deikun, and R. L. Schlotterbeck. 2017. Effects of amount of colostrum replacer, amount of milk replacer, and housing cleanliness on health, growth, and intake of Holstein calves to 8 weeks of age. J. Dairy Sci. 100:9177-9185.

Quigley, J. D., T. M. Hill, T. S. Dennis, F. X. Suarez-Mena, and R. L. Schlotterbeck. 2018. Effects of feeding milk replacer at 2 rates with pelleted, low-starch or texturized, high-starch starters on calf performance and digestion. J. Dairy Sci. 101:5937-5948.

Quigley, J. D., R. E. Strohbehn, C. J. Kost, and M. M. O'Brien. 2001. Formulation of colostrum supplements, colostrum replacers and acquisition of passive immunity in neonatal calves. J. Dairy Sci. 84:2059-2065.

Radostits, O. M., and J. M. Bell. 1968. Nutrient digestibility by newborn calves fed milk replacer. Can. J. Anim. Sci. 48:293-302.

Robertson, J. B., and P. J. Van Soest. 1981. The Detergent System of Analysis and its Application to Human Foods. Cornell University, Ithaca, NY

Roffler, B., A. Fah, S. N. Sauter, H. M. Hammon, P. Gallmann, G. Brem, and J. W. Blum. 2003. Intestinal morphology, epithelial cell proliferation, and absorptive capacity in neonatal calves fed milkborn insulin-like growth factor-I or a colostrum extract. J. Dairy Sci. 86:1797-1806.

Russell, R. W., E. V. Caruolo, and G. H. Wise. 1980. Effects of pregastric esterase on utilization of whole milk by preruminant calves. J. Dairy Sci. 63:1114-1122.

Spurlock, M. E. 1997. Regulation of metabolism and growth during immune challenge: An overview of cytokine function. J. Anim. Sci. 75:1773-1783.

Steinhoff-Wagner, J., S. Görs, P. Junghans, R. M. Bruckmaier, E. Kanitz, C. C. Metges, and H. M. Hammon. 2011. Intestinal glucose absorption but not endogenous glucose production differs between colostrum- and formula-fed neonatal calves. J. Nutr. 141:48-55.

Steinhoff-Wagner, J., R. Zitnan, U. Schönhusen, H. Pfannkuche, M. Hudakova, C. C. Metges, and H. M. Hammon. 2014. Diet effects on glucose absorption in the small intestine of neonatal calves: Importance of intestinal mucosal growth, lactase activity, and glucose transporters. J. Dairy Sci. 97:6358-6369.

Swan, H., S. Godden, R. Bey, S. Wells, J. Fetrow, and H. ChesterJones. 2007. Passive transfer of immunoglobulin $G$ and preweaning health in Holstein calves fed a commercial colostrum replacer. J. Dairy Sci. 90:3857-3866.

Terosky, T. L., A. J. Heinrichs, and L. L. Wilson. 1997. A comparison of milk protein sources in diets of calves up to eight weeks of age. J. Dairy Sci. 80:2977-2983.

Van Soest, P. J., J. B. Robertson, and B. A. Lewis. 1991. Methods for dietary fiber, neutral detergent fiber, non-starch polysaccharides in relation to animal nutrition. Symposium: Carbohydrate methodology, metabolism and nutritional implications in dairy cattle. J. Dairy Sci. 74:3583-3597.

Wildman, E. E., G. M. Jones, P. E. Wagner, R. L. Bowman, H. F. Troutt Jr., and T. N. Lesch. 1982. A dairy cow body condition scoring system and its relationship to selected production characteristics. J. Dairy Sci. 65:495-501.

Yang, M., Y. Zou, Z. H. Wu, S. L. Li, and Z. J. Cao. 2015. Colostrum quality affects immune system establishment and intestinal development of neonatal calves. J. Dairy Sci. 98:7153-7163.

\section{ORCIDS}

J. D. Quigley (®) https://orcid.org/0000-0001-8400-8963

L. Deikun (ㄱ https://orcid.org/0000-0002-5143-6571

T. M. Hill ๑ https://orcid.org/0000-0003-1304-5016

F. X. Suarez-Mena @ https://orcid.org/0000-0002-1546-5893

T. S. Dennis (ㄴ) https://orcid.org/0000-0003-3424-5498

W. Hu ๑ https://orcid.org/0000-0002-1307-3458 